\title{
Cerebellar border zone infarcts are often associated with presumed cardiac sources of ischaemic stroke
}

\author{
F Mounier-Vehier, I Degaey, X Leclerc, D Leys
}

Department of

Neurology

F Mounier-Vehier

I Degaey

$D$ Leys

Department of

France

$\mathrm{X}$ Leclerc

Correspondence to:

Dr F Mounier-Vehier,

Service de Neurologie $B$

Hôpital B, 59037 Lille

Cedex, France.

Received 22 August 1994

and in revised form

2 December 1994

Accepted 3 March 1995
Neuroradiology

University of Lille,

\begin{abstract}
It has been suggested that most border zone cerebellar infarcts are embolic infarcts or infarcts due to hypercoagulable states. The aim of this study was to test this hypothesis.

Risk factors for the presumed mechanism of stroke (TOAST criteria) were studied in 14 consecutive patients (nine men, five women; age range 29-84 years) with a total of 17 border zone cerebellar infarcts.
\end{abstract}

The presumed cause of stroke was "cardioembolism" in nine patients. Three patients had a dissection of the vertebral artery. Two patients had a negative diagnostic investigation, and one had a cardiac arrest.

These findings support the hypothesis that cardioembolism is a frequent mechanism of border zone cerebellar infarcts.

$(\mathcal{F}$ Neurol Neurosurg Psychiatry 1995;59:87-89)

Keywords: cerebellar infarct; cardioembolism; stroke; cerebrovascular disease

Breakdown of the age, sex, vascular risk factors, type, and side of the border zone cerebellar infarcts (criteria of Amarenco et al ${ }^{5}$ ) and presumed cause of the stroke (TOAST criteria $^{8}$ )

\begin{tabular}{|c|c|c|c|c|c|}
\hline $\begin{array}{l}\text { Patient } \\
\text { No }\end{array}$ & Age & Sex & $\begin{array}{l}\text { Vascular risk } \\
\text { factors }\end{array}$ & $\begin{array}{l}\text { Type of cerebellar } \\
\text { border zone infarcts }\end{array}$ & $\begin{array}{l}\text { Presumed } \\
\text { cause }\end{array}$ \\
\hline $\begin{array}{l}1 \\
2\end{array}$ & $\begin{array}{l}73 \\
64\end{array}$ & $\begin{array}{l}\mathbf{M} \\
\mathbf{M}\end{array}$ & $\begin{array}{l}\text { HTN } \\
\text { HTN, tobacco }\end{array}$ & $\begin{array}{l}1(\mathrm{R}) \\
5(\mathrm{~L})\end{array}$ & $\begin{array}{l}\text { Undetermined } \\
\text { Cardiac } \\
\text { (septal akinesia) }\end{array}$ \\
\hline 3 & 72 & $\mathbf{M}$ & HTN, tobacco & $2(\mathrm{~L})$ and $(\mathrm{R})$ & $\begin{array}{l}\text { Undetermined } \\
\text { (cardiogenic shock) }\end{array}$ \\
\hline 4 & 42 & $\mathrm{~F}$ & None & $1 \mathrm{R}$ & $\begin{array}{l}\text { Cardiac } \\
\text { (PFO and ASA) }\end{array}$ \\
\hline 5 & 32 & $F$ & $\begin{array}{l}\text { HTN, tobacco, } \\
\text { dyslipaemia }\end{array}$ & $1(\mathrm{R})$ and $2(\mathrm{~L})$ & $\begin{array}{l}\text { Cardiac } \\
\text { (PFO) }\end{array}$ \\
\hline 6 & 35 & $\mathbf{M}$ & Dyslipaemia & $4(\mathrm{~L})$ & $\begin{array}{l}\text { Cardiac } \\
\text { (PFO and ASA) }\end{array}$ \\
\hline 7 & 80 & $\mathrm{~F}$ & HTN & $4(\mathrm{R})$ & $\begin{array}{l}\text { Cardiac } \\
\text { (atrial fibrillation) }\end{array}$ \\
\hline 8 & 68 & $\mathbf{M}$ & Tobacco & $1(\mathrm{~L})$ & $\begin{array}{l}\text { Cardiac } \\
\text { (septal akinesia) }\end{array}$ \\
\hline 9 & 84 & $\mathrm{~F}$ & None & $1(\mathrm{~L})$ & $\begin{array}{l}\text { Cardiac } \\
\text { (atrial fibrillation) }\end{array}$ \\
\hline 10 & 29 & $\mathbf{M}$ & Dyslipaemia & $5(\mathrm{R})$ & $\begin{array}{l}\text { Other determined } \\
\text { (VA dissection) }\end{array}$ \\
\hline 11 & 34 & F & None & $1(\mathrm{R})$ and $2(\mathrm{R})$ & $\begin{array}{l}\text { Other determined } \\
\text { (VA dissection) }\end{array}$ \\
\hline 12 & 42 & $\mathbf{M}$ & HTN, tobacco & $1(\mathrm{~L})$ & $\begin{array}{l}\text { Other determined } \\
\text { (VA dissection) }\end{array}$ \\
\hline 13 & 54 & $\mathbf{M}$ & None & $3(\mathrm{R})$ & $\begin{array}{l}\text { Cardiac } \\
\text { (left atrial thrombus) }\end{array}$ \\
\hline 14 & 50 & $\mathbf{M}$ & None & $1(\mathrm{R})$ & $\begin{array}{l}\text { Cardiac } \\
\text { (prothetic valve) }\end{array}$ \\
\hline
\end{tabular}

HTN = hypertension; PFO = patent foramen ovale; $\mathrm{ASA}=$ atrial septal aneurysm; VA = vertebral artery; $R=$ right; $L=$ left.
Cerebellar infarcts account for about $2 \%$ of cerebral infarcts. ${ }^{1}$ Whereas previous studies took into account territorial cerebellar infarcts, ${ }^{1-4}$ Amarenco et $a l^{5}$ identified a subgroup of border zone cerebellar infarcts. Their most striking clinical characteristic is the long duration of positional symptoms. ${ }^{5}$ Their cause remains uncertain. ${ }^{5}$ Supratentorial border zone infarcts are usually regarded as low flow infarcts ${ }^{6}$ but the recently categorised cerebellar border zone infarcts might be embolic infarcts or associated with a hypercoagulable state. ${ }^{7}$

The aim of our study was to describe the presumed mechanism of stroke in 14 patients with border zone cerebellar infarcts by means of a systematic search for large vessel atherosclerosis and cardioembolism.

Patients and methods

We conducted this study over a 19 month period (1 June 1992-31 December 1993) in 300 emergency admissions for ischaemic stroke or transient ischaemic attacks. During the study period, 11 patients $(3.6 \%)$ had one border zone cerebellar infarct or more. During the same period three other patients referred from other hospitals for vertebrobasilar transient ischaemia attacks had a border zone cerebellar infarct identified on MRI.

The study population consisted of nine men and five women, aged from 29 to 84 years. None of these patients had a history of neurosurgery, severe head trauma, or cerebral arterial or arteriovenous malformation. All patients underwent standard blood tests (including sedimentation rate, fibrinogen, packed cell volume, platelet count, and coagulation tests), 12 lead electrocardiography, and 24 hour continuous electrocardiography monitoring. We performed bidimensional transthoracic echocardiography or transesophageal echocardiography in all patients. All patients had an MRI except one who had two CT scans. The cervical arteries were studied by doppler ultrasonography and B mode echotomography in all patients, and complete cerebral angiography, including the subclavian and vertebral arteries, was performed in five.

Computed tomography was done without contrast with $5 \mathrm{~mm}$ contiguous slices using a Siemens Somatom II machine (Siemens, 


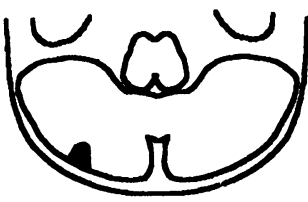

Patient 1

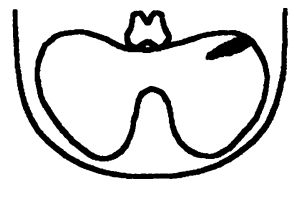

Patient 2

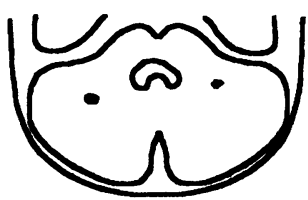

Patient 3

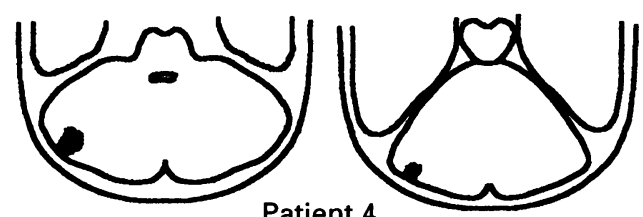

Patient 4

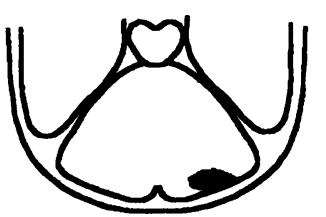

Patient 6

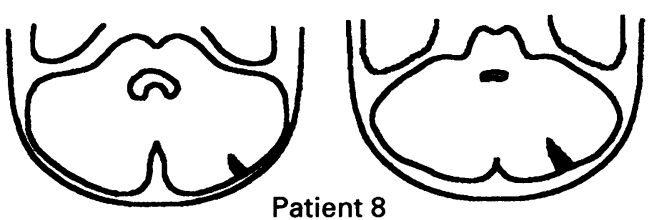

Patient 8

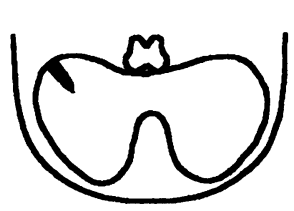

Patient 10

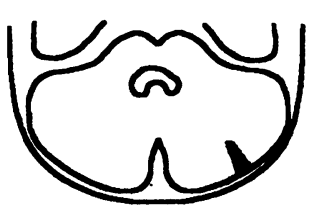

Patient 12

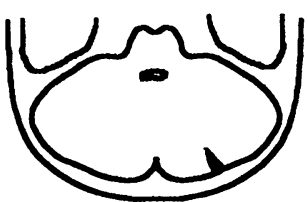

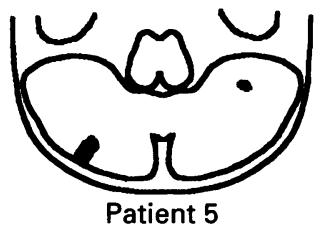

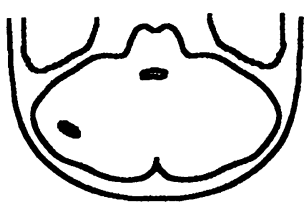

Patient 7

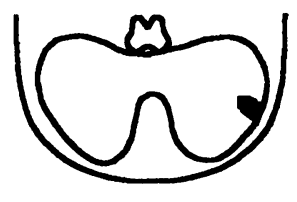

Patient 9

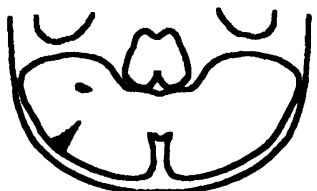

Patient 11

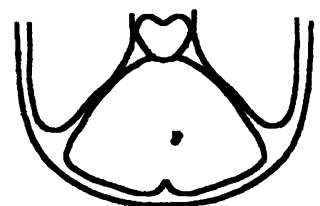

Patient 13

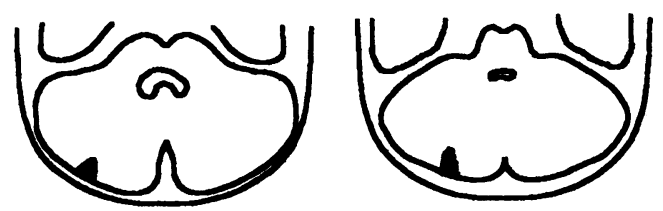

Patient 14

Location of the 17 border zone cerebellar infarcts in the 14 patients.

Germany). Magnetic resonance imaging was carried out on an MR max machine (General Electric, USA) with a superconducting magnet operating at a field strength of 0.5 Tesla. We used axial MRI with T1 weighted (repetition time, $300 \mathrm{~ms}$; echo time, $22 \mathrm{~ms}$ ) and T2 weighted spin echo sequences (repetition time, two seconds; two echo time of 30 and $60 \mathrm{~ms}$ ), and $6 \mathrm{~mm}$ slice thickness with a 6 $\mathrm{mm}$ gap. Types and size of infarcts were determined on MRI and on the second CT in the patient who did not undergo MRI. We defined a border zone cerebellar infarct as a very small cerebellar infarct localisable between well defined arterial cerebellar terri- tories. ${ }^{5}$ These infarcts were classified into five groups according to the criteria of Amarenco et $a l^{5}$ : group 1 at the boundary zone between posterior inferior and superior cerebellar artery territories; group 2 between superior, posteroinferior, and anterior cerebellar artery territories; group 3 between both superior cerebellar arteries; group 4 between superficial branches of the superior and inferior cerebellar arteries; group 5 between anterior and posteroinferior cerebellar artery territories.

The presumed causes of stroke were defined according to the criteria used by Adams et al in the trial of Org 10172 in acute stroke treatment (TOAST). ${ }^{8}$

\section{Results}

Table 1 presents the results of the study.

The 14 patients shared a total of 17 border zone cerebellar infarcts: eight in group 1, four in group 2 , one in group 3 , two in group 4, and two in group 5 . The presumed mechanism was a cardioembolism (high risk) in four patients: mitral and aortic prosthetic valves in one, left atrial thrombus in one, and septal post myocardial infarction akinesia in two. A medium risk source of cardioembolism was found in five patients: lone atrial fibrillation in two, atrial septal aneurysm associated with a patent foramen ovale in two, and isolated patent foramen ovale in one. Three patients had a dissection of one vertebral artery. One patient with a negative diagnostic assessment and one with a severe cardiogenic shock were classified in the group of undetermined cause.

No patient had a large vessel atherosclerosis as the presumed mechanism of stroke and the erythrocyte sedimentation rate, platelet count, packed cell volume, coagulation test, and serum fibrinogen concentration were normal in all patients.

The figure shows the locations of the infarcts in the 14 patients.

\section{Discussion}

Our study showed that, of 14 patients with one or more border zone cerebellar infarcts, nine had a potential cardiac source of stroke. Cardiac sources of emboli were more frequent in our study than in previous reports on border zone cerebellar infarcts. Severe vertebrobasilar atherosclerosis was the presumed cause in the eight patients of Barth et al. ${ }^{9} \mathrm{~A}$ focal cerebellar hypoperfusion was present in 27 patients from the 47 of the first study of Amarenco et al. ${ }^{5}$ In this series large artery disease was the principal cause (16 patients) of stroke and only seven patients had a cardiac source of embolism. In a more recent study, ${ }^{7}$ performed on a smaller group (36 patients), the cause of the border zone cerebellar infarct was a cardioembolism in $42 \%$. In our study three patients had large artery disease, and the nine patients with cardiac disease did not have large artery occlusion.

As three patients out of nine with potential cardiac sources of stroke had arterial hypertension, we cannot exclude small vessel 
occlusion as the most likely cause of stroke in these patients with coincidental cardiac sources of embolism. The TOAST criteria ${ }^{8}$ may lead to an underestimation of the prevalence of small vessel occlusion.

Except for the patient with a cardiac arrest all patients had a complete diagnostic assessment. Only one patient was classified in the undetermined cause group by the TOAST criteria; this was less than in the studies of Amarenco et al. ${ }^{57}$ Surprisingly no patient had a hypercoagulable state whereas it was the third most common aetiology of border zone cerebellar infarcts in the study of Amarenco et $a l .^{7}$

As in the previous studies ${ }^{57}$ haemodynamic causes of stroke were rare, suggesting that low flow infarcts are less frequent in border zone cerebellar infarcts than in supratentorial border zone infarcts. The exact cause of stroke in patient with heart disease and no evidence of focal hypoperfusion, however, remains uncertain. A haemodynamic mechanism cannot be excluded. Moreover the role of cardioembolism in the pathogenesis of supratentorial border zone infarcts could have been underestimated, especially in internal junctional infarcts. ${ }^{10}$

Cardioembolism may be a frequent cause of border zone cerebellar infarcts; hence, appropriate cardiac investigations are necessary in these patients.

This work was supported in part by a grant from the "Direction de la Recherche et des Etudes Doctorales".

1 Tohgi H, Takahashi S, Chiba K, Hirata Y, for the Tohgi H, Takahashi S, Chiba K, Hirata Y, for the infarction: clinical and neuroimaging analysis in 293 infarction: clinical and neuroimagi

2 Sypert GW, Alvord EC. Cerebellar infarction: a clinicopathological study. Arch Neurol 1975;32:357-63.

3 Amarenco P, Haw JJ. Cerebellar infarction in the territory of the anterior and inferior cerebellar artery: a clinicopathological study of 20 cases. Brain 1990;113:139-55.

4 Kase CS, Norrving B, Levine SR, Babikian VL, Chodosh EH, Wolf PA, Welch KMA. Cerebellar infarction: clini$\mathrm{cal}$ and anatomic observations in 66 cases. Stroke 1993; 24:76-83.

5 Amarenco P, Kase CS, Rosengart A, Pessin MS, Bousser MG, Caplan LR. Very small (border zone) cerebellar infarcts. Brain 1993;116:161-86.

6 Torvik A. The pathogenesis of watershed infarcts in the brain. Stroke 1984;15:221-3.

7 Amarenco P, Levy C, Cohen A, Touboul PJ, Roullet E, Bousser MG. Causes and mechanisms of territorial and nonterritorial cerebellar infarcts in 115 consecutive patients. Stroke 1994;25:105-12.

8 Adams HP Jr, Bendixen BH, Kappelle LJ, Biller J, Love $\mathrm{BB}$, Gordon DL, Marsh III EE and the TOAST investigators. Classification of subtypes of acute ischaemic stroke. Definitions for use in a multicenter clinical trial. Stroke 1993;24:35-41.

9 Barth A, Bogousslavsky J, Regli F. The clinical and topographic spectrum of cerebellar infarcts: a clinical-magnetic resonance imaging correlation study. Ann Neurol 1993;33:451-6.

10 Mounier-Vehier F, Leys D, Godefroy O, Rondepierre P Marchau M, Pruvo JP. Border zone infarcts subtypes: preliminary study of the presumed mechanism. Eur preliminary study of 